\title{
Land Degradation by Soil Erosion in Nepal: A Review
}

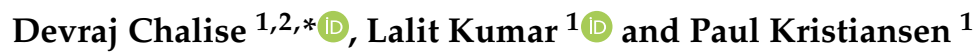 \\ 1 School of Environmental and Rural Science, University of New England, Armidale, NSW 2351, Australia; \\ lkumar@une.edu.au (L.K.); pkristi2@une.edu.au (P.K.) \\ 2 National Maize Research Program, Nepal Agricultural Research Council, P.O. Box 44209, Chitwan, Nepal \\ * Correspondence: dchalise@myune.edu.au or chalisedevraj@gmail.com
}

Received: 18 November 2018; Accepted: 5 February 2019; Published: 8 February 2019

\begin{abstract}
Land degradation, particularly soil erosion, is currently a major challenge for Nepal. With a high rate of population growth, subsistence-based rural economy, and increasingly intense rainfall events in the monsoon season, Nepal is prone to several forms of land degradation, such as floods, landslides, and soil erosion. To understand the causes, impacts, and possible management options for soil erosion, a review on the causal factors, status, and amelioration measures for land degradation in Nepal was conducted based on recent information available in national and international journals and grey literature. Intense rainfall and conventional tillage practices coupled with poor soil structure and steep slopes are the main drivers of soil erosion. Soil erosion leads to losses in soil and crop productivity, pollution of land and water resources, and a loss of farm income. Strategies to manage erosion include mulching, cover cropping, contour farming, strip cropping, and conservation agriculture practices, along with bioengineering techniques. Land degradation issues are a prime policy focus in Nepal, including national three- and five-year plans. However, these policies have been generally ineffective in reducing soil erosion, landslides, and floods in relation to the set targets. Realistic plans need to be formulated in Nepal focusing more on capacity enhancement and local participation to actively influence land-degradation processes.
\end{abstract}

Keywords: conservation tillage; land-use; nutrient loss; soil erosion

\section{Introduction}

Land degradation involves deterioration in soil properties related to crop production, infrastructure maintenance, and natural resource quality [1]. It is also associated with the decline in the productivity of ecosystems over time [2]. It may include acidification, alkalisation, depletion of soil nutrients, and reduction in soil organic matter (SOM), compaction, soil erosion, and loss of biodiversity [3]. Land degradation occurs via various physical, biological, and chemical processes induced by human activities either directly or indirectly. About $60 \%$ of the world's land area is regarded as degraded and land degradation, including soil erosion, is one of the greatest challenges for land managers [4]. Soil erosion, in particular, is a serious problem and poses major concerns worldwide [5].

Nepal is a country with significant social and geographical diversity and it faces a range of serious land degradation issues [6]. The increasing population and decreasing agricultural productivity are current challenges for the country [7]. Agricultural soils have been deteriorating with time and there has been increasing pressure on utilising forest resources to fulfil peoples' basic food needs. Intense cultivation [8] and excessive use of chemical fertilisers have seriously degraded soil fertility and soil erosion has been a continual problem for agricultural productivity and the environment.

It is estimated that $1.7 \mathrm{~mm}$ of topsoil is lost each year due to soil erosion, but it takes almost 100 years to form $1 \mathrm{~cm}$ of soil [9]. About $21,000 \mathrm{~m}^{3}$ of soil, equivalent to $64 \mathrm{tha}^{-1}$, is being eroded 
annually in the Khajuri catchment of Siwalik Hills of Nepal [7]. In another soil erosion study undertaken in the Koshi basin of Nepal, soil loss of up to $22 \mathrm{tha}^{-1}$ year $^{-1}$ in the barren lands were reported [10]. Mean soil loss rate of $11.17 \mathrm{t} \mathrm{ha}^{-1}$ year $^{-1}$ was estimated in the Aringale Khola watershed of Nepal which indicated a major part of the watershed was degraded [11]. Variation in topography, land-use land cover changes, unequal distribution of rainfall, and varying demography across the country produce different rates of soil erosion.

Few researchers have studied land degradation scenarios in Nepal. Erosion plot measurements techniques were the most common to calculate the intensity of soil erosion in the Nepalese terrains before 2000 [12-20], whereas the soil erosion modeling methods became common thereafter. Grey literature used to be the first choice for publication for soil erosion studies until about 2000 [12-20]; thereafter soil erosion research started to appear in national and international journals. Therefore, we considered diverse sources of literature that refer to the causes and impacts of soil erosion in Nepal, and possible restoration measures. Specific issues covered in this review include the types of land degradation in different physiographic zones of Nepal, the causes of land degradation, the consequences on crop productivity and land-use, and land management practices and national initiatives to address land degradation and soil erosion. The findings of this review will be beneficial to researchers, land managers, and decision makers in understanding land degradation in Nepal and developing suitable practices and planning for policies to alleviate the problem effectively.

\section{Land Degradation in Nepal}

Nepal lies between $26^{\circ} 22^{\prime}$ and $30^{\circ} 27^{\prime}$ North and $80^{\circ} 04^{\prime}$ and $88^{\circ} 12^{\prime}$ East and comprises five distinct physiographical regions namely the Terai Plains, Siwalik Hills, Middle Mountains, High Mountains, and High Himalayas (Source: Survey Department, Ministry of Land Management, Cooperatives and Poverty Alleviation, http:/ / dos.gov.np). Approximately 97\% of total area (147, $181 \mathrm{~km}^{2}$ ) of Nepal is land, elevation of which extends from $60 \mathrm{~m}$ (Terai Plains) to $8848 \mathrm{~m}$ (Mount Everest) (Figure 1; Figure 2).

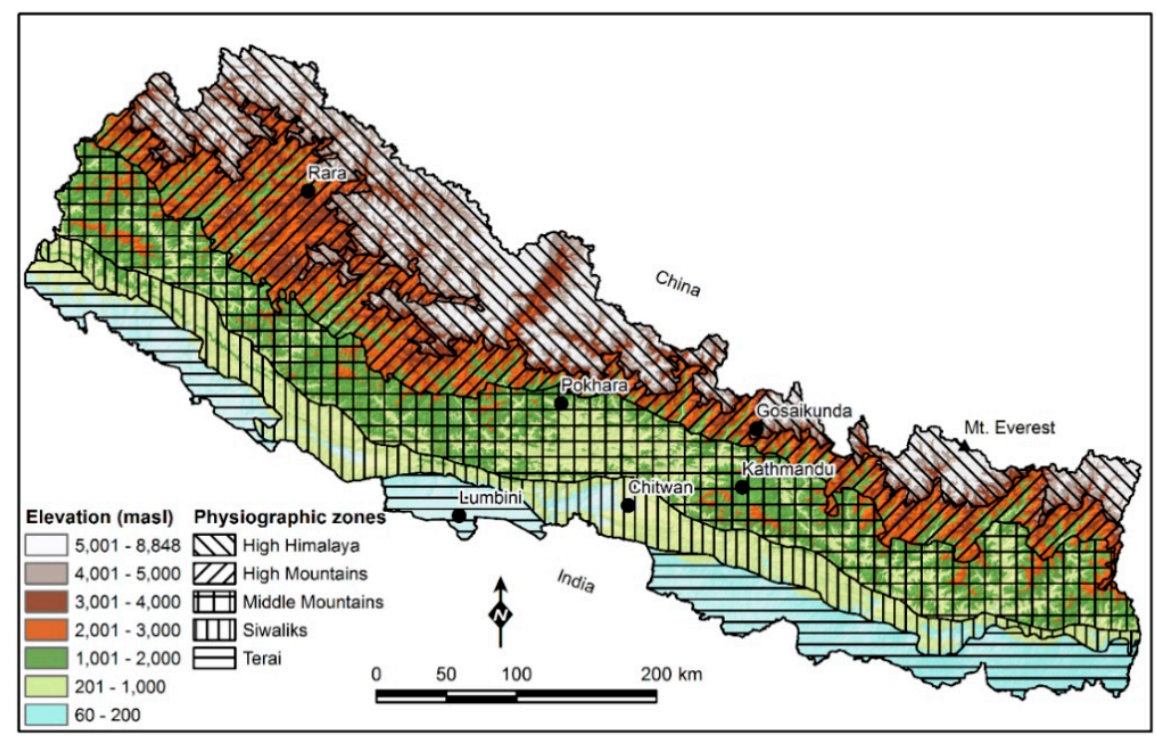

Figure 1. Physiographic regions of Nepal (Source: Survey Department, Ministry of Land Management, Cooperatives and Poverty Alleviation, http://dos.gov.np/).

The Terai Plains extend $800 \mathrm{~km}$ (East-West) and 30 to $40 \mathrm{~km}$ (North-South) with an elevation ranging from 60 to $700 \mathrm{~m}$. The slope of the Siwalik Hills abruptly increases from Terai, and elevations range from 700 to $1500 \mathrm{~m}$. The Middle Mountains act as the first barrier to monsoon rain and their elevation extend from 1500 to $2700 \mathrm{~m}$. The High Mountains are $50 \mathrm{~km}$ wide and elevation ranges from 2000 to $4000 \mathrm{~m}$. The snow-covered High Himalayas extend from 4000 to $8848 \mathrm{~m}$ elevation [6,21]. It is 
important to note that the physiographic regions overlap each other for the elevations so the elevation described here is in the range values (Table 1).

A significant variation is found with the topography, land-use patterns, and the population and development pressures within the physiographic regions which produces different types of land degradation [6] (Table 1). The Terai Plains and Siwalik Hills are typically characterized by the topography of lower elevations and gentle slopes, where dominant forms of land degradation are damage from flooding, waterlogging, and shifting of river courses, sheet, rill, inter-rill, and gully erosion. Unlike the Terai Plains and Siwalik Hills, the Middle Mountains, High Mountains and High Himalayas are of rugged and undulating topography; most of them are steeply sloped so they experience different genres of land degradation; and they are often harsh and severe namely rill and inter-rill erosion, mass wasting, bank cutting, rock slides, and in a severe condition an outburst of glacial lakes [6].
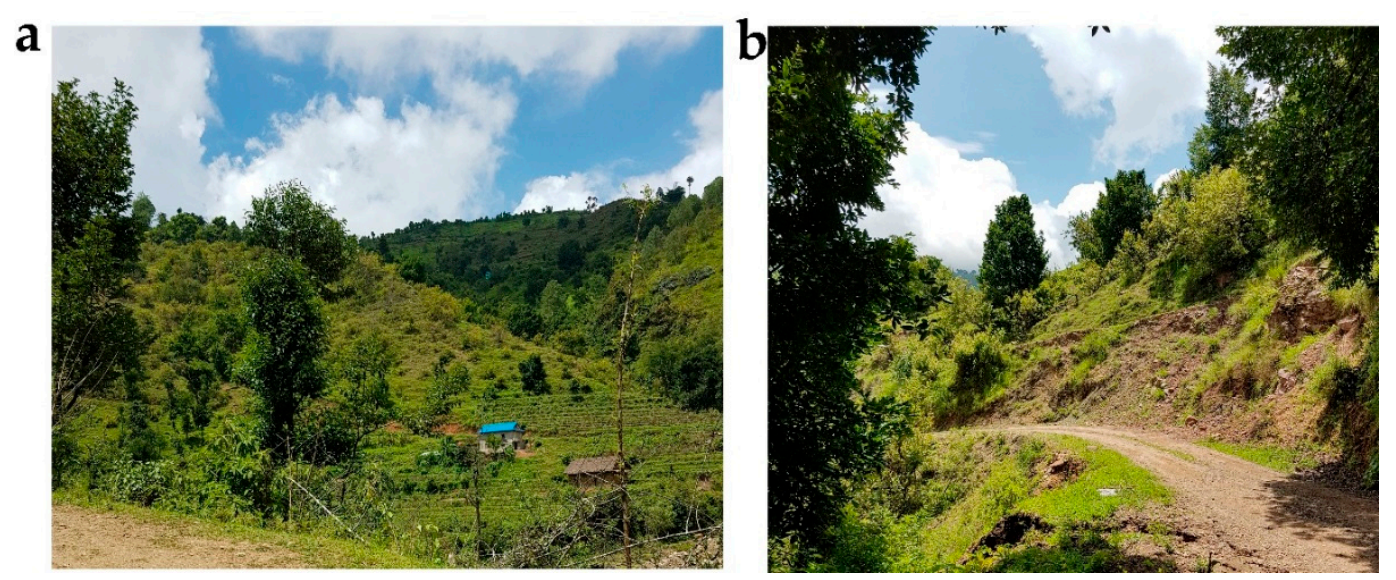

Figure 2. The typical terrace based farming system (a) and soil loss by erosion/landslide (b) in the middle hills of Nepal (Photos taken on August 2017).

Table 1. Types of land degradation in the physiographic regions of Nepal (Adapted from [6,21,22]).

\begin{tabular}{ccc}
\hline Physiographic Regions & Elevation $(\mathbf{m})$ & Common Land Degradation Types \\
\hline High Himalayas & $4000-8848$ & Rock slides, an outburst of glacial lakes \\
High Mountains & $2000-4000$ & Mass wasting, bank cutting, rill, and inter-rill erosion \\
Middle Mountains & $1500-2700$ & Mass wasting, rill erosion, inter-rill erosion, and bank cutting \\
Siwalik Hills & $700-1500$ & Rill, inter-rill, and gully erosion \\
Terai Plains & $60-700$ & Flooding, water logging, sheet erosion, and shifting of river \\
& & courses leading to streambank erosion \\
\hline
\end{tabular}

Physical land degradation includes soil structural deterioration with increased bulk density, a decrease in the effective soil pores, and increased runoff [1]. It includes compaction of soil by heavy tillage implements such as tractors and harvesters. A further cause of physical degradation is grazing pressure on land. Cows and buffaloes in Nepal are allowed free grazing on public grassland thereby leading to soil compaction, removal of vegetation and leaf litter, and finally increasing the susceptibility of soil to water and wind erosion [6]. In 2006, physical land degradation alone caused the deterioration of about 0.2 million ha of land, roughly $1.4 \%$ of the total land area of Nepal [23].

Soil biological degradation is related to the improper use of chemical fertilisers, pesticides, and land-use practices which reduce SOM [6]. Unsustainable farming without rotational tillage and heavy input of chemical amendments in agricultural fields is common in Nepal, including on steep slopes in the hilly regions. Impacts include a reduction in the amount and diversity of soil organisms, an occurrence of soil-borne diseases, and a decrease in soil biota functions such as soil aggregation and nutrient retention [6]. 
The improper use of synthetic fertilisers and pesticides may also cause chemical land degradation. This can manifest as a slow buildup of crop protection compounds that may hinder plant growth and development, soil nutrient depletion, and reduced agricultural production. Loss of nutrients and SOM, salinisation, acidification, and chemical pollution are some of the distinguished chemical degradation processes worldwide. Less research has been undertaken into chemically mediated land degradation in Nepal [24]. Some studies show that the plant nutrient balance is negative at the national level [25]. Amongst all nutrients, loss of nitrogen is the highest as compared to potassium and phosphorus. Although chemical fertilisers are being increasingly used, overall erosion rates are relatively low and have few effects on the environment; however, in specific areas where there is overuse of chemical fertilisers, adverse effects on plant, water, and soil have been reported [26]. Biological and chemical degradation of soil may be due to the same reason of "fertiliser and pesticide application" as described here. However, it is important to note the impacts. We referred to biological degradation as reduction in the amount and diversity of soil organisms and the decrease in soil functions whereas the chemical degradation is related to the buildup of chemical compounds that restrict the plant growth.

It is estimated that 3.16 million hectares ( $11.81 \%$ of the total area of Nepal) have been affected by the degradation process [26] (Table 2). Approximately $38 \%$ of forest lands, $37 \%$ of pasture/rangeland, and $10 \%$ of agricultural land were seriously degraded. Floods and landslides damaged nearly $1 \%$ of the area between 1984 and 2003 [26].

Table 2. Degraded land area by land-use (adapted from [26]).

\begin{tabular}{cccc}
\hline Types of Land-Use & $\begin{array}{c}\text { Total Degraded Land } \\
\text { (million ha) }\end{array}$ & $\begin{array}{c}\text { Total Land Area } \\
\text { (million ha) }\end{array}$ & Degraded Land (\%) \\
\hline Forest & 2.22 & 5.83 & 38.07 \\
Pasture/rangeland & 0.65 & 1.75 & 36.97 \\
Agriculture (sloping terraces) & 0.29 & 2.97 & 9.77 \\
\hline
\end{tabular}

The consequences of land degradation and soil erosion are manifold. Human-induced activities such as overgrazing, unsustainable farming, excessive use of hazardous chemical fertilisers and pesticides, and deforestation have resulted in the loss of topsoil and biodiversity. Landslides and soil erosion processes occurring in hilly regions cause damage to peoples' lives and property, and runoff water from the hills may contribute to flooding in the plains.

\section{Accelerated Soil Erosion and Its Causes}

\subsection{Impacts of Land-Use on Erosion}

The rate with which the land and soil degrade depends on the rate of land cover degradation which is aggravated by land-use management and adverse climates. Vegetation cover, type and distribution of land-use, and its management are the major factors controlling the frequency of occurrence of soil erosion [27]. In a research conducted in the Landruk village of Nepal, the loss of nitrate-nitrogen was estimated to be $0.7-5.6 \mathrm{~kg} \mathrm{ha}^{-1} \mathrm{year}^{-1}$ in the surface runoff in the rainfed bench terraced cropping system [28].

Most of the agriculturally influenced soil and land degradation is seen in the rainfed Bari land (upland) than in the irrigated Khet land (lowland) in Nepal since people are more focused on increasing rice productivity in the Khet land [24]. Agricultural lands in Nepal have experienced soil erosion rates of zero in the lowland areas to $420 \mathrm{t} \mathrm{ha}^{-1}$ year $^{-1}$ in the shrub lands [29] (Table 3). The lowland paddy fields are characterised by level bench terraces so there is a minimum of soil losses by erosion. In contrast, upland areas are known to have sloping terraces with different breadths and slopes hence having varying rates of soil erosion. Average soil loss in the forested land was estimated to be $5.1 \mathrm{tha}^{-1}$ year $^{-1}$ whereas the shrub lands lost soil about 12 times more as compared to the forests [29]. Higher rates of erosion in the shrub lands than in the forests may be due to steep slopes, lack of 
plant cover, surface layer compaction, and formation of rills and gullies. About 1.75 million ha of rangeland/open land, 1.12 million ha of agricultural land, and 1.56 million ha of forest land needed immediate adoption of scientific land management techniques in order to minimise soil erosion and improve resource productivity [26].

Table 3. Land-use types and erosion rate (adapted from [29]).

\begin{tabular}{ccc}
\hline Land-Use & Average Soil Loss $\left(\mathbf{t ~ h a}^{\mathbf{- 1}}\right.$ year $\left.^{\mathbf{- 1}}\right)$ & Range $_{(\mathbf{t ~ h a}} \mathbf{H}^{\mathbf{1}}$ year $\left.^{\mathbf{- 1}}\right)$ \\
\hline Upland & $28 \pm 29$ & $2-105$ \\
Lowland & $0.7 \pm 0.9$ & $0-2.7$ \\
Shrub & $58 \pm 78$ & $0.4-420$ \\
Forest & $5.1 \pm 4.7$ & $0.2-15.3$ \\
\hline
\end{tabular}

Note: \pm denotes the standard deviation.

Long-term land-use cover change (LUCC) affects soil erosion [30-34]. The mutual impact of LUCC and soil erosion has become a major environmental dispute in the recent decade as strong effects of LUCC on soil loss and sediment discharges have been identified [35]. While analysing the LUCC in the Sarada, Rapti, and Thuli Bheri river basins of western Nepal during the period of 1995 to 2015, we found an overall decrease of the area under the forests and water bodies and an increase in the agricultural and built-up areas. As a result, the soil erosion rate increased from $5.35 \mathrm{t} \mathrm{ha}^{-1} \mathrm{year}^{-1}$ in 1995 to $6.03 \mathrm{t} \mathrm{ha}^{-1}$ year $^{-1}$ in 2015 [36]. It is important to note here that this data is from our ongoing research where erosion rates were calculated using the Revised Universal Soil Loss Equation (RUSLE) and Geographical Information System (GIS) in three important river basins of Nepal namely Sarada, Rapti, and Thuli Bheri.

\subsection{Impacts of Environmental Factors on Erosion}

Soil loss from a given landscape by erosion largely depends upon the intensity and duration of rainfall occurring in that place. The detaching power of falling raindrops striking on the land surface and its contribution to runoff is mainly responsible for soil loss by rain or subsequent water erosion [37]. The recorded average annual rainfall in Nepal varies from $163 \mathrm{~mm}$ in Mustang to $5244 \mathrm{~mm}$ in Pokhara [26]. Intense rainfalls of long duration mostly occur during the monsoon (June to September) in Nepal when $80 \%$ of the annual rain falls (Figure 3). Therefore, a considerable amount of soil loss is likely to occur in the hilly regions with steep slopes during this season.

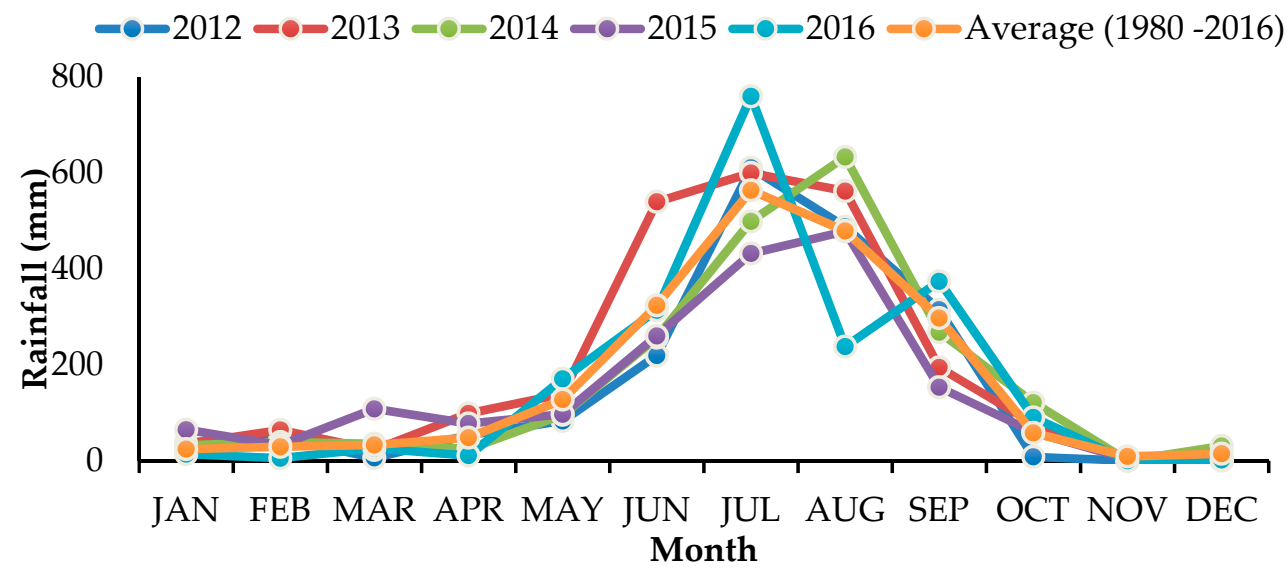

Figure 3. Mean monthly rainfall (mm) in western Nepal for the years 2012-2016 and the average for 1980 to 2016. The rainfall data of 13 stations were retrieved from Department of Hydrology and Meteorology, Nepal (See Table S1). 
The volume of annual rainfall varied from 1147 to $1716 \mathrm{~mm}$, through the years (Figure 4). Similarly, the rainfall erosivity factor (440-639 $\mathrm{MJ} \mathrm{mm} \mathrm{ha}{ }^{-1} \mathrm{~h}^{-1}$ year $^{-1}$ ) calculated from annual rainfall data did not appear to be increasing or decreasing over the same period of time. In contrast, the soil erosion rates have increased; mean rates were 5.35, 5.47 and $6.03 \mathrm{t} \mathrm{ha}^{-1}$ year $^{-1}$ in 1995, 2007 and 2015, respectively [36]. This may be explained in the context of climate change since the number of rainy days is decreasing but the rainfall volume is not changing. Therefore, the same amount of rain is falling with greater intensity, leading to a worsening erosion problem during the monsoon season.

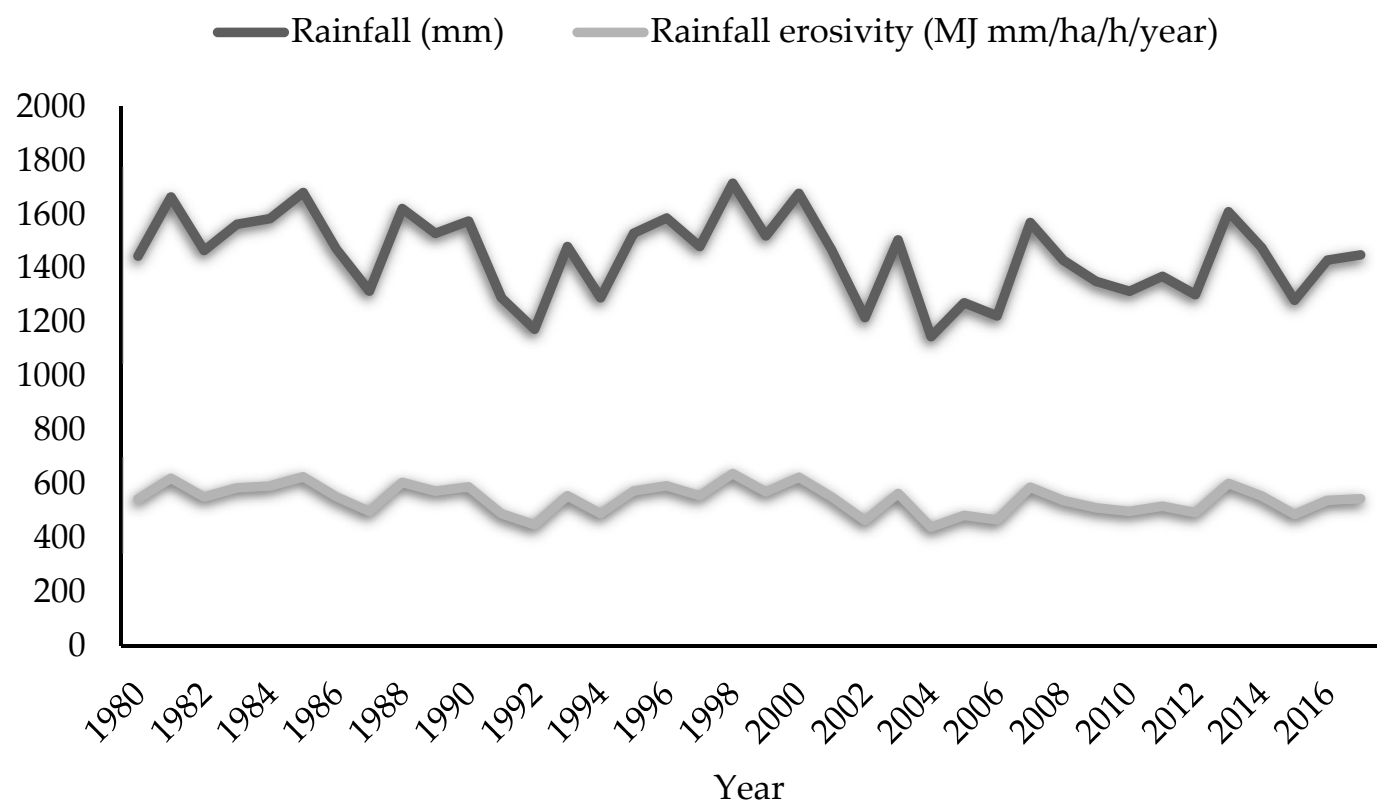

Figure 4. Variation in rainfall and rainfall erosivity $(\mathrm{R})$ over the years in western Nepal. The R factor was calculated using the formula, $\mathrm{R}=38.5+0.35 \mathrm{r}$ as given by Harper [38], where $\mathrm{r}$ is mean annual rainfall in $\mathrm{mm}$. The rainfall data of 53 stations were retrieved from Department of Hydrology and Meteorology, Nepal (See Table S2).

The ease with which the soil erodes also depends on the arrangement of soil aggregates. Soils containing low SOM content, with fine texture, and weak structure are most susceptible to soil erosion [4]. Reduced SOM level in the rainfed cultivated uplands of Nepal is responsible for increased soil erosion in the area [24]. These soils have very low infiltration rates and are more prone to water and soil erosion. The loss of the topsoil including the disintegration of soil aggregates is the most severe process that affects the sustainability of farming systems in the mountain regions of Nepal. An increase in soil structural stability and vegetative cover significantly reduces soil erosion.

Increased grazing pressure, particularly in the Terai and Hills of Nepal, has seriously degraded soil physical conditions including the water and nutrient holding capacity of soil [39] thus exposing it to loss by erosion and landslides. Livestock grazing speeds up the soil erosion process as regular trampling of land by a large number of animals breaks up the soil aggregates and makes the soil compact [40].

The topography of the landscape finally determines the rate at which the soil is being eroded [4]. Soil erosion is normally expected to increase with an increase in steepness and length of slope [41] that may result in an increase in the volume and velocity of surface runoff. Falling raindrops on flat land splash soil aggregates randomly in all directions, whereas soils on a steep slope are splashed down the slope thus causing more erosion [37]. Nepal, characterized by a wide range of elevations and the presence of variable slopes ranging from gentle to steep slopes in the Siwalik Hills, Mountains and Himalaya regions, suffers from mild to severe soil erosion. Rainfall and earthquakes are the triggering factors to make these regions more vulnerable to erosion, landslides, and mass wasting [42]. 


\subsection{Impacts of Management Factors on Erosion}

The practice of tilling land several times before the onset of monsoon is very common in Nepal, however, it makes land bare prior to crop planting. High-intensity rainfalls are accompanied by strong winds during the monsoon season, thus making the soil more susceptible to erosion [43]. Maize, a major crop grown in the hills of Nepal, requires extensive soil tillage operations. After harvesting, most of the maize stalks are removed from the field and then ploughed repeatedly after farmyard manure application [44]. This makes soil exposed and prone to soil erosion by both water and wind. There is a need to replace these unsustainable conventional tillage practices [44] with minimum or reduced tillage [45]. As compared to conventional tillage, reduced tillage practices minimised annual soil loss by $33 \%$ in the middle hills of Nepal [44].

Vegetation cover prevents soil erosion by means of the roots, canopy, and litter [46]. Soil loss has been severe during the pre-monsoon season in Nepal when there is no vegetation in the field [44,47]. During this season, it is estimated that 60 to $80 \%$ of the total soil and nutrients are lost [48]. Land that is covered by plants, either living or dead, are more protected and less affected by soil erosion. In developing countries with high population, the loss of soil cover is very common where agricultural and forest management practices are not adequate to protect soils [4].

\section{Erosion Effects on Nutrient Loss and Crop Productivity}

The cumulative effects of soil erosion on agriculture are seen after many years. Soil erosion may lead to reduced crop production and it will be difficult to correct using locally available technologies. Soil erosion affects crop productivity by reducing nitrogen, phosphorus, and SOM reserves, varying clay content of the soil, depleting available water capacity, and reducing soil aggregation [49]. It is reported that SOM, nitrate-nitrogen, zinc, phosphorus, and iron get decreased whereas $\mathrm{pH}$, potassium, and calcium get increased in severe forms of soil erosion [50].

The impacts of severe soil erosion may be both environmental and economic. Economic impacts are borne of loss of farm household income as crop and farm animal production are reduced whereas pollution of land and natural water brings the environmental impacts. Also, the impacts of soil erosion on productivity can be both on-site and off-site. On-site effects are associated with nutrients loss, crop damage, and loss of fertile topsoil whereas off-site impacts are water contamination, blockage of waterways by soil sediments, and damage to physical infrastructures [51]. The condition is severe when there is a loss of topsoil depth. In the cultivated fields of a steep slope, tillage-induced erosion is also responsible for the loss of topsoil besides rain and wind erosion [52].

As most of the SOM is located on the topsoil, several researchers have indicated that soils lost by erosion are 1.3 to 5 times richer in SOM than the soils left behind [53]. With the traditional conventional tillage practices, soil loss of $16.6 \mathrm{t} \mathrm{ha}^{-1}$ was estimated in the maize-growing middle hills of Nepal [44], which constitute a corresponding annual loss of $188 \mathrm{~kg}$ organic carbon, $18.8 \mathrm{~kg}$ nitrogen and $3.8 \mathrm{~kg}$ potassium per hectare, respectively. Deforestation, expanded cultivation, and overgrazing are the major factors contributing to increased runoff and soil erosion leading to low productivity and poverty (Figure 5). 


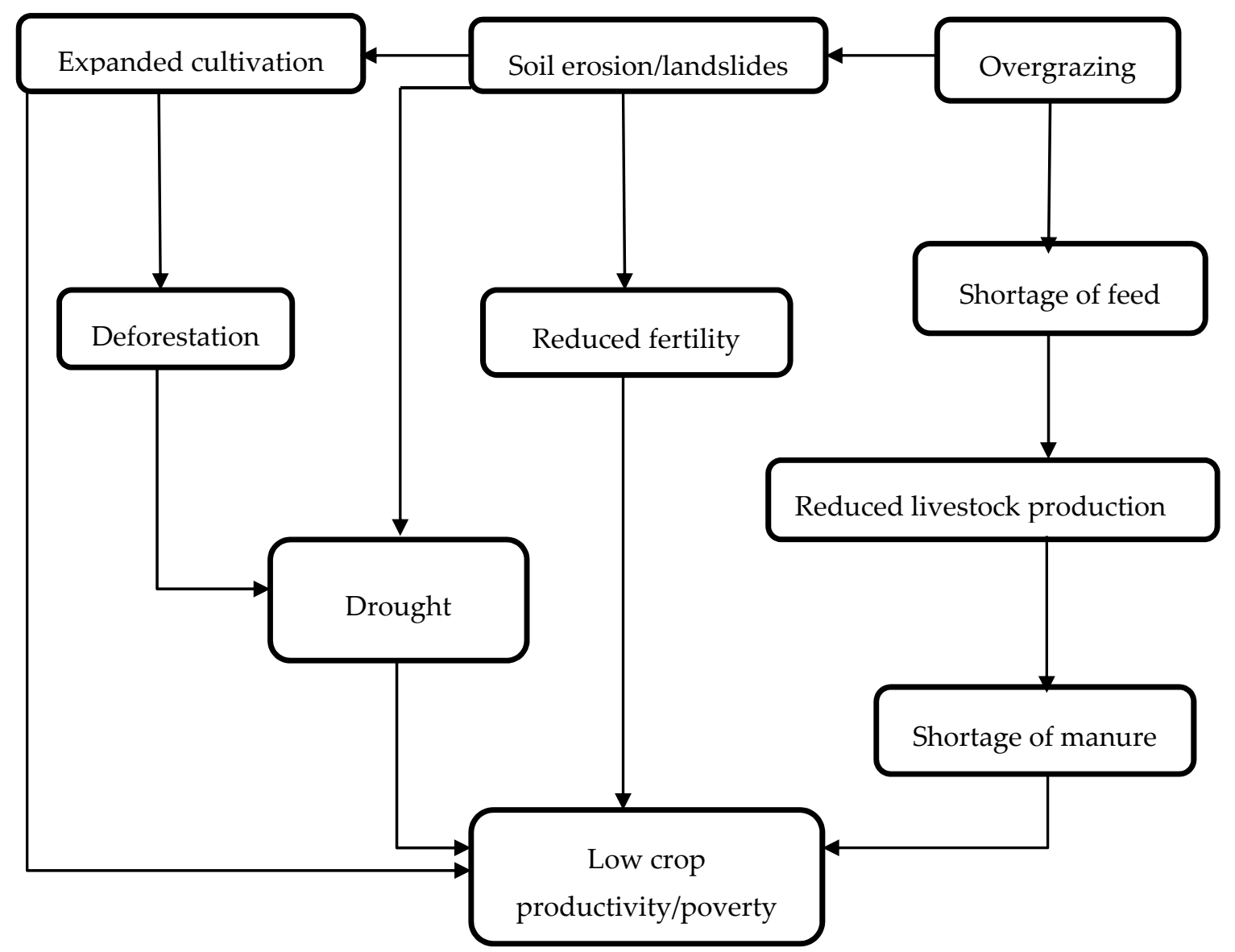

Figure 5. Negative effects of soil erosion (Source: Lecture notes from Ram Kumar Shrestha, 2013).

\section{Restoration Measures}

Restoring degraded agricultural lands in Nepal is a major task. Accelerated soil erosion coupled with high surface runoff is a major problem on newly cleared land, so early implementation of suitable erosion management measures is important. Effective soil erosion management can be done by:

- Maintaining vegetative cover to minimise direct impacts of raindrops and to impede surface flow [46];

- Improving soil physical conditions to prevent crusting, increase infiltration and reduce surface runoff, and adopting conservation agricultural practices [54];

- Removing excess water overflow through suitable engineering techniques [55]; and

- Following agricultural practices such as terracing so as to reduce slope length [56] to minimise the build-up of surface runoff.

Management of soil erosion can be done by two key approaches: agronomic/soil management and mechanical measures (Figure 6). Contouring, mulching, and conservation agriculture practices are effective for soil management whereas cover cropping, strip cropping, multiple cropping, and high-density planting [57] are the agronomic management practices that deal with soil erosion. Terracing, bunding, and waterways come under runoff and slope management [58]. 


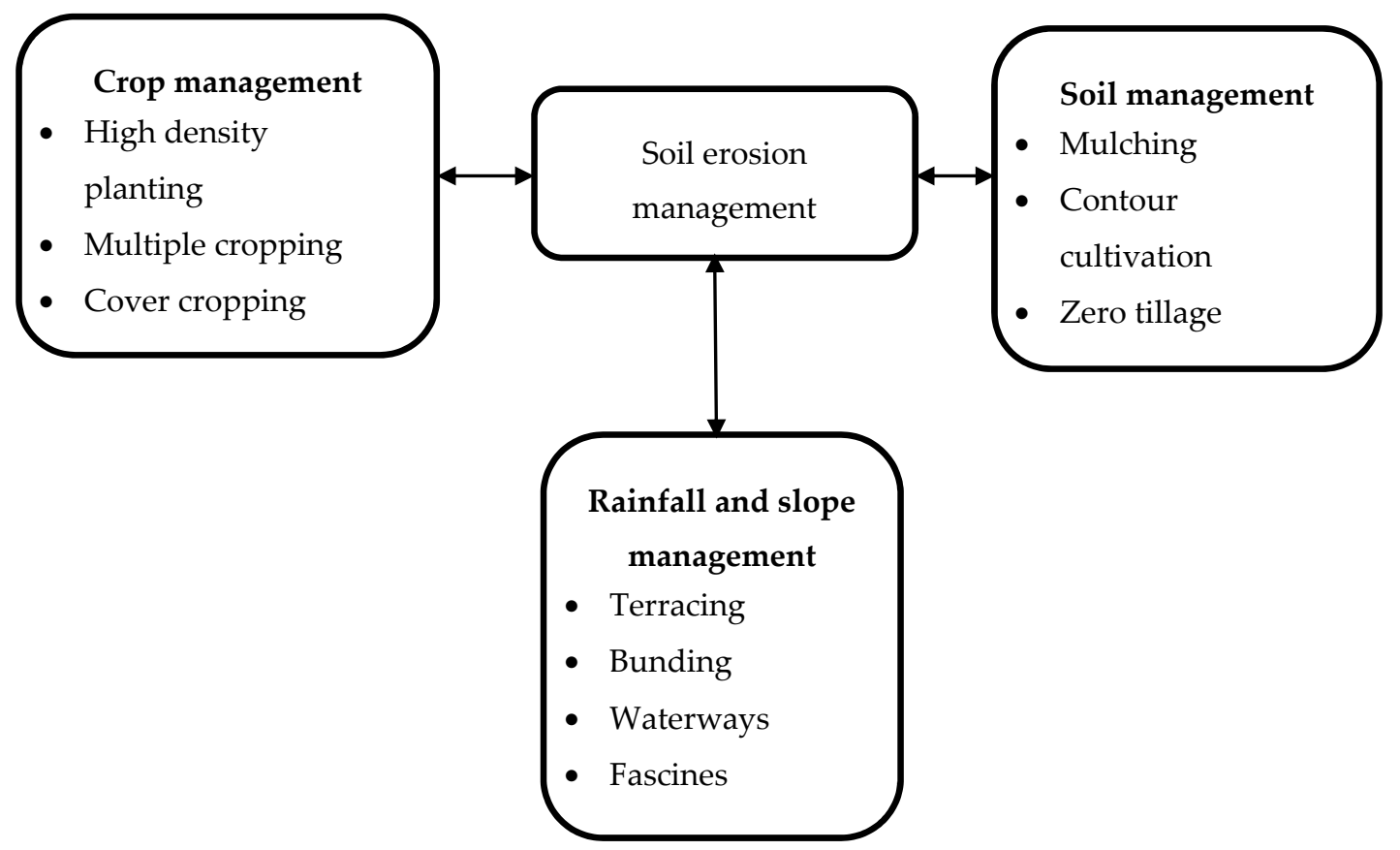

Figure 6. Management of soil erosion.

\subsection{Manuring and Fertilisation}

Adequate manuring and fertilisation help to maintain a healthy population of crops. Plants that cover ground quickly are the best insurance against accelerated soil erosion [59] (Figure 7). The balanced application and monitoring of plant nutrients are critical for crop productivity and soil functioning. An application of cow dung slurry on the soil surface reduced the detachment of soils by raindrop impacts up to $70 \%$ in the UK [60]. Organic manures in combination with chemical fertilisers improve the water-holding capacity of soil and other physical conditions thus reducing the impacts of soil erosion.
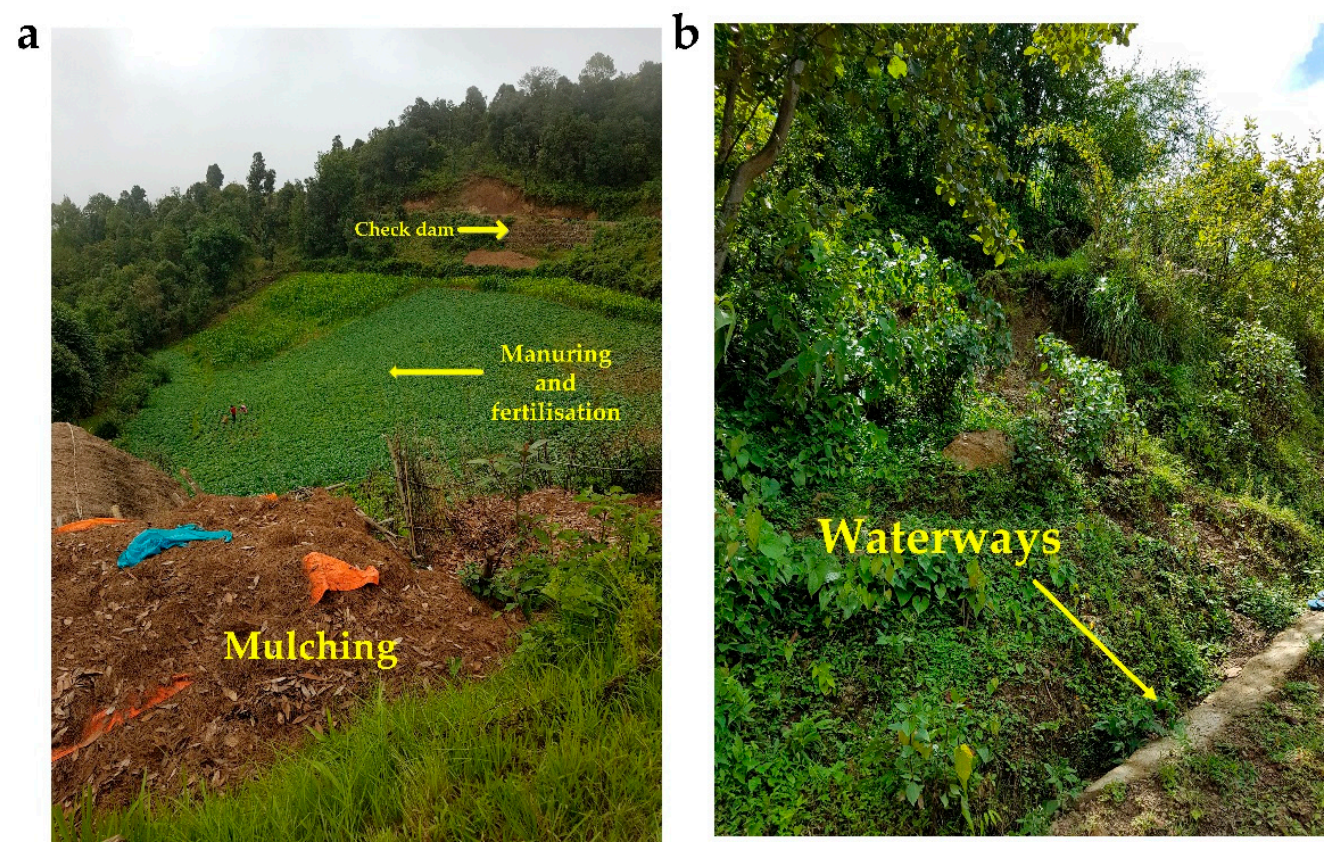

Figure 7. Popular restoration measures to reduce soil erosion in the middle hills of Nepal (Photos taken on August 2017). 


\subsection{Mulching}

The beneficial effects of mulching on reducing soil erosion are due to two main reasons. Firstly, it helps to reduce runoff losses as mulching improves infiltration of water into the soil. Next, it decreases sediment concentration by minimising rill and inter-rill erosion through improvements in soil structure and the protective effects of crop residues against the direct impact of raindrops. Reduction in soil runoff up to $18 \%$ was reported with the use of rice straw mulching in Kathmandu, Nepal [43] (Table 4).

Table 4. Restoration measures to combat with soil erosion in Nepal as reported by various authors.

\begin{tabular}{|c|c|c|c|}
\hline $\begin{array}{l}\text { Restoration } \\
\text { Measures }\end{array}$ & Study Area and Methods & Key Findings & Reference \\
\hline Mulching & $\begin{array}{l}\text { Maize planting with reduced tillage } \\
\text { and rice straw mulching in } \\
\text { Kathmandu University }\end{array}$ & Mulching reduced soil runoff by $18 \%$ & Atreya, et al. [43] \\
\hline Strip planting & $\begin{array}{l}\text { Strip planting with maize and } \\
\text { legumes in the Palpa district }\end{array}$ & $\begin{array}{l}\text { Strip crop technologies effective in } \\
\text { reducing soil erosion through } \\
\text { sieve-barrier effect }\end{array}$ & $\begin{array}{l}\text { Acharya, et al. } \\
\text { [61] }\end{array}$ \\
\hline Cover cropping & $\begin{array}{c}\text { Planting Napier grass on devastated } \\
\text { gully catchment of the Pipaltar, } \\
\text { Nuwakot district }\end{array}$ & $\begin{array}{l}\text { Restored soil fertility and recovered } \\
\text { the catchment (1995 to 2003) }\end{array}$ & Higaki, et al. [62] \\
\hline \multirow[t]{2}{*}{ Reduced tillage } & $\begin{array}{l}\text { Maize planting with conventional and } \\
\text { reduced tillage practices in } \\
\text { Kathmandu University }\end{array}$ & $\begin{array}{l}\text { Compared to conventional tillage, } \\
\text { reduced tillage decreased the loss of } \\
\text { soil organic carbon, total nitrogen and } \\
\text { exchangeable potassium by } 62,7 \text { and } \\
1.4 \mathrm{~kg} \mathrm{ha}^{-1} \text {, respectively }\end{array}$ & Atreya, et al. [44] \\
\hline & $\begin{array}{l}\text { Maize, cowpea, finger millet and } \\
\text { capsicum planting with reduced and } \\
\text { conventional tillage practices in the } \\
\text { Pokhare Khola watershed }\end{array}$ & $\begin{array}{l}\text { In comparison with conventional } \\
\text { tillage, reduced tillage decreased soil } \\
\text { erosion and sediment runoff by } 23 \% \\
\text { and } 9 \% \text {, respectively. }\end{array}$ & Tiwari, et al. [63] \\
\hline \multirow[t]{2}{*}{ Check dams } & $\begin{array}{l}\text { Planting Dalbergia sisso, Eucalyptus } \\
\text { camaldulensis and bamboo along with } \\
\text { small check dams in the degraded } \\
\text { stream of the Sarlahi district }\end{array}$ & $\begin{array}{l}\text { Stabilised the streams, reduced } \\
\text { landslides, and soil erosion over } \\
\text { a period of four years (2006 to 2010) }\end{array}$ & Dhital, et al. [64] \\
\hline & $\begin{array}{l}\text { Use of vegetative and wire net check } \\
\text { dams in the Bagmati river basin }\end{array}$ & $\begin{array}{c}\text { Narrowed the flow of stream channels } \\
\text { and reduced the river cuttings on } \\
\text { the streambanks }\end{array}$ & $\begin{array}{c}\text { Dhital and Tang } \\
\text { [65] }\end{array}$ \\
\hline \multirow[b]{2}{*}{ Hedgerows } & $\begin{array}{l}\text { Planting hedgerows in the contours in } \\
\text { Godavari, Kathmandu }\end{array}$ & Reduction of soil loss by $80-99 \%$ & $\begin{array}{c}\text { Ya and Nakarmi } \\
\text { [66] }\end{array}$ \\
\hline & $\begin{array}{l}\text { Hedgerows with intercropping } \\
\text { systems to assess the effectiveness of } \\
\text { SALT in Godavari, Kathmandu }\end{array}$ & $\begin{array}{l}\text { Hedgerows significantly lowered } \\
\text { runoff by } 38-43 \% \text { and soil loss by } \\
72-89 \% \text {, respectively }\end{array}$ & Lamichhane [67] \\
\hline
\end{tabular}

\subsection{Cover Crop Management}

Cover crops cover the soil surface with their dense foliage to reduce the negative effects of soil erosion. They reduce the volume of runoff water and soil erosion, and increase soil productivity [68]. Cover crops protect the soil from splashing of raindrops, build up SOM content, suppress weeds, and minimise changes in microclimate around plants. Most of the surface cover also impedes water flow and thus increases infiltration, reduces runoff, and further minimises erosion. Planting Napier (Pennisetum purpureum), in the degraded catchment of Pipaltar, Nepal, demonstrated its value in restoring soil fertility and recovering the badly degraded gully catchment from 1995 to 2003 [62] (Table 4).

\subsection{Strip Planting}

Strip planting is a practice of growing erosion-permitting row crops in alternate strips with erosion-checking close-growing crops and grasses. Plant strips established in sloping lands reduce runoff and soil erosion [69]. Erosion-checking crops, e.g., lentil and barley, generally have dense foliage 
so as to reduce the impacts of soil erosion. With this practice, erosion is restricted to row crops and eroded soil material is trapped in the erosion-checking strips. For effective soil erosion control, planting should be rotated each year so that erosion-checking crops grow on an area where erosion-permitting row crops were planted earlier and vice versa. Acharya, et al. [61] reported the efficacy of strip crop technologies in reducing soil erosion in the Palpa district of Nepal (Table 4).

\subsection{Contour Farming}

Contour farming (also known as contour planting, contour cultivation or simply contouring) involves field operations such as ploughing, harrowing, furrowing, and planting being done along the contours of the land. Cultivation across slopes produces an effective barrier against water runoff, reducing its velocity, and hence minimising soil erosion. Better water conservation in the soil also benefits crop yields [70].

\subsection{Conservation Tillage}

Conservation tillage may be defined as any method of soil cultivation that leaves at least $30 \%$ of crop residues on the land surface after cultivation [71]. Retaining the previous year's crop residues on the field before or after planting the next crop effectively reduces soil erosion and runoff. Soil disturbance by excessive tillage is a key reason for the degradation of soil structure and accelerated soil erosion. The intensity and frequency of tillage are minimised and plant residues remain in situ. Conservation tillage such as no-till and reduced/minimum tillage is effective in bringing positive changes to soil physical, biological, and chemical properties thereby improving soil and water reserve [72]. In an experiment conducted in the middle hills of Nepal, in comparison to conventional tillage, the reduced tillage decreased the loss of soil organic carbon, total nitrogen and exchangeable potassium by 62,7 and $1.4 \mathrm{~kg} \mathrm{ha}^{-1}$, respectively [9]. Reduced/minimum tillage minimised the soil erosion and sediment runoff by $23 \%$ and $9 \%$, respectively in the Pokhare Khola watershed of the Dhading district of Nepal [63] (Table 4).

\subsection{Bioengineering Techniques}

The use of bioengineering to prevent soil erosion in Nepal started 30 years ago in the form of live check dams, brush layering, hedgerows, and fascines [64]. It is the use of living plant materials so as to provide some engineering functions. It judiciously uses plants in combination with different engineering methods to prevent the problems of soil erosion. Planting native species like Dalbergia sisso, Eucalyptus camaldulensis, and bamboo along the small check dams of eroded stream banks in the Sarlahi district of Nepal stabilised the streams and significantly reduced landslides and soil erosion within a four-year period (2006 to 2010) [64] (Table 4). The use of vegetative and wire net check dams in the Bagmati river basin stabilised streambanks, narrowed the flow of stream channels, and minimised the river cuttings on the streambanks [65].

Formation of bunds by hedgerows reduces the steepness, forms natural terraces, and reduces runoff and soil erosion [73]. After five years of planting, well-maintained hedgerows in the contours significantly reduced the soil loss by $80-99 \%$ in the Godavari, Kathmandu, Nepal [66].

\section{National Initiatives to Cope with Soil Erosion and Land Degradation}

In order to cope with the problem of land degradation, a number of initiatives have been taken at different institutional and national levels in Nepal. These include the formulation and enactment of national acts and policies, building and maintaining institutions for the implementation of different projects and missions in restoring the fertility of partially degraded land and desertified lands [26]. Although there is no specific act or law in combating land degradation, some sectoral policies and five-year national periodical plans have raised the issue of land and soil degradation.

The Eighth Five Year Plan (1992 to 1997) was targeted at preserving the forest in the Chure and Bhawar regions of Nepal to control the river cuttings and landslides, and aimed at providing incentives 
to promote community or leasehold forest in the marginal land [74]. The Ninth Five Year Plan (1997 to 2002) emphasised reducing the adverse effects of increased landslides and high population growth on the environment and institutionalisation of land-use planning and environmental impact assessment (EIA) [75]. The Tenth Five Year Plan (2002 to 2007) indicated that the use of marginal land for agricultural production and land-fragmentation were primary reasons for the low productivity of the agricultural sector [76]. The Tenth Plan, therefore, aimed at achieving sustainable development through the judicious use of natural resources including land [26]. The Thirteenth Three Year Plan (2013 to 2016) also envisaged forest and soil conservation, stating that about $23 \%$ of Nepal's total area be labelled as areas for conservation so as to preserve the environment and biodiversity [77]. The current Fourteenth Three Year Plan (2017 to 2020) is aimed at furbishing National Land Use Policy 2006 to classify the lands more scientifically and enforce laws on land-use throughout the country [78]. The National Agricultural Policy, 2004, and Agriculture Perspective Plan, 1995 to 2015, both were aimed at increasing agricultural growth, emphasising market expansion with investment in irrigation, roads, fertilisers, and technologies [26]. Although these periodic plans have focused on agricultural development with a priority to capacity enhancement, the growth rate of agricultural productivity is very slow and the incidence of landslides, floods, and soil erosion are increasing [26]. Table 5 lists periodic planning documents along with the expected outcomes, achievements, shortcomings, and recommendations. These plans mainly focused on afforestation, leasehold forest management, formation of community forest users' groups (CFUGs), and extension of community soil conservation services throughout the country as important means to combat land degradation. Some of the targets were easily achieved, yet many were less successful. Forest encroachment, uncontrolled grazing, forest fires, and soil erosion were the major hindrances for achieving the targets. The lack of coordination between CFUGs and government bodies was a major problem for each periodic plan to meet their expectations. Nepal needs more coordinated efforts in formulating policies that ensure decentralisation and local participation.

Nepal took part in the preparatory processes of the United Nations Convention to Combat Desertification (UNCCD), officially adopted from 13 January 1997. The main objective was to combat land degradation and desertification and reduce the ill effects of drought [26]. The Soil and Water Conservation Act 1982 had prohibited cutting down the existing forests and the collection of stone, sand or mud in vulnerable land or land likely to be vulnerable to any natural disasters [79]. In the water sector, six policy documents have been formulated (Water Resource Strategy 2002; National Wetland Policy 2003; Irrigation Policy 2003; National Water Plan 2005; Water Induced Disaster Management Policy 2005 and Irrigation Development Vision 2006) and have focused on sustainable watershed management, prioritising efficient irrigation and mitigation of water-induced disasters including soil erosion [26]. Similarly, the Millennium Development Goals 2000; Sustainable Development Agenda for Nepal 2003; Terai Arc Landscape Strategy 2004; and Land Use Policy and Strategy 2005 have also emphasised land and water conservation in one way or the other [26]. 
Table 5. Periodic plans of Nepal, expected outcomes, achievements, shortcomings and recommendations

\begin{tabular}{|c|c|c|c|c|}
\hline Plan & Expected Outcomes & Achievements & Shortcomings & Recommendations \\
\hline 8th & $\begin{array}{l}\text { - Community soil conservation services } \\
\text { - } \quad \text { Afforgeted to extend in } 60 \text { districts } \\
\text { - } \quad \text { Leasehold forest management: } \\
\text { - } \quad 50,000 \text { families } \\
\text { - } 5004 \text { CFUGs formation } \\
\end{array}$ & $\begin{array}{l}\text { - } \quad \text { Extended to just } 50 \text { districts } \\
\text { - } \quad \text { Afforestation: } 26,456 \text { ha } \\
\text { - } 2432 \text { families } \\
\text { - } 5316 \text { CFUGs formed }\end{array}$ & $\begin{array}{l}\text { Lack of infrastructures for } \\
\text { commercialisation of agriculture }\end{array}$ & $\begin{array}{l}\text { Modification and strengthening of } \\
\text { planning process is required }\end{array}$ \\
\hline 9th & $\begin{array}{l}\text { Community soil conservation service } \\
\text { extension to } 75 \text { districts }\end{array}$ & Extended to 55 districts only & $\begin{array}{l}\text { No order situation hindered the } \\
\text { implementation and budget diverted to } \\
\text { the security sector }\end{array}$ & $\begin{array}{l}\text { Necessary to bring hitherto left-out } \\
\text { groups into the mainstream, focus on } \\
\text { proper mobilisation, allocation, and } \\
\text { utilisation of available resources }\end{array}$ \\
\hline 10th & $\begin{array}{l}\text { - Leasehold forestry: } 6500 \text { ha } \\
\text { - Community integrated watershed } \\
\text { management: } 110 \text { sub-watersheds } \\
\text { - CFUGs formation: } 2500\end{array}$ & $\begin{array}{l}\text { - } \quad \text { Leasehold forestry: } 7553 \text { ha } \\
\text { - Community integrated watershed } \\
\text { management: } 152 \text { watersheds } \\
\text { - CFUGs: } 2500\end{array}$ & $\begin{array}{l}\text { Lack of coordination in the } \\
\text { management of community, leasehold, } \\
\text { and government-owned forests }\end{array}$ & $\begin{array}{l}\text { A district-level strategic plan should be } \\
\text { developed and adequate public } \\
\text { participation should be ensured. }\end{array}$ \\
\hline 11th & Formation of new CFUGs: 2500 & CFUGs: 15,000 (total up to this plan) & $\begin{array}{l}\text { Forest encroachment, soil erosion, } \\
\text { forest fires }\end{array}$ & $\begin{array}{c}\text { Formulation of policies focusing on } \\
\text { decentralisation and local participation }\end{array}$ \\
\hline 12th & $\begin{array}{l}\text { - Community integrated watershed } \\
\text { management: } 400 \text { sub-watersheds } \\
\text { - } \quad \text { Formation of new CFUGs: } 1700\end{array}$ & $\begin{array}{l}\text { - Community integrated watershed } \\
\text { management: } 343 \text { sub-watersheds } \\
\text { - } \quad \text { No of CFUGs: } 18,000 \text { (total) }\end{array}$ & $\begin{array}{l}\text { Forest encroachment, soil erosion, } \\
\text { forest fires, uncontrolled grazing }\end{array}$ & $\begin{array}{l}\text { Formulation of policies focusing on } \\
\text { decentralisation and local participation }\end{array}$ \\
\hline 13th & $\begin{array}{l}\text { Increase area under forests by at least } 40 \% \\
\text { from } 39.6 \%\end{array}$ & Area under forests reached $44.5 \%$ & $\begin{array}{l}\text { Devastating earthquake (April 2015), } \\
\text { forest encroachment, forest fires }\end{array}$ & $\begin{array}{l}\text { Formulation of policies focusing on } \\
\text { decentralisation and local participation }\end{array}$ \\
\hline 14th & $\begin{array}{l}\text { Landslide control on } 2000 \text { places, water } \\
\text { source conservation in } 600 \text { places }\end{array}$ & & Running & \\
\hline
\end{tabular}




\section{Conclusions}

This paper reviewed the nature and causes of land degradation focusing on soil erosion and considered the negative impacts on agriculture and the environment, possible restoration measures, and national initiatives taken so far to address the problem of soil erosion and land degradation in Nepal. Nepal, a mountainous country with strong population growth and intense rainfall events, is highly susceptible to soil erosion, floods, and landslides. Concentrated rainfall events in the monsoon, weak soil structure, undulating land morphology, excessive tillage operations, and the practice of vegetation removal aggravate soil erosion and land degradation. Erosion leads to a loss of fertile topsoil, removal of plant nutrients and SOM, and reduction of soil productivity for agriculture.

Implementing suitable erosion management measures is needed to prevent land from being irreversibly damaged by soil erosion. Soil erosion management includes a range of agronomic, soil management, and mechanical measures. Some of them include contour cultivation, mulching, cover cropping, high-density planting, conservation agriculture practices, terracing, bunding, and waterways. Similarly, bioengineering techniques are of paramount importance in stabilising streambanks and reducing landslides in degraded river basins.

There is no single legislative act and/or policy formulated to combat land degradation in Nepal. However, there are numerous sectoral policies and periodical plans of the Nepalese government that have listed soil and land degradation management as a high priority. While land degradation issues have been addressed in almost every three- and five-year periodic plans, the incidence of floods, soil erosion, and landslides has not decreased as expected. Nepal consequently needs to prepare periodic plans which are more realistic, emphasising capacity enhancement, local participation, and infrastructure strengthening.

Supplementary Materials: The following are available online at http://www.mdpi.com/2571-8789/3/1/12/s1.

Author Contributions: Conceptualization, D.C., L.K. and P.K.; Methodology, D.C.; Resources, D.C.; Writing-Original Draft Preparation, D.C. and L.K.; Writing-Review and Editing, D.C., L.K. and P.K.

Funding: D.C. prepared this manuscript as a part of his $\mathrm{PhD}$ research funded by the International Postgraduate Research Award provided by the University of New England, Australia.

Acknowledgments: The authors would like to thank anonymous reviewers and editors for bringing this manuscript in the current shape.

Conflicts of Interest: The authors declare no conflict of interest. The funding sponsors had no role in the design of the study; in the collection, analyses, or interpretation of data; in the writing of the manuscript, and in the decision to publish the results.

\section{References}

1. Lal, R. Soil degradation by erosion. Land Degrad. Dev. 2001, 12, 519-539. [CrossRef]

2. Turner, K.G.; Anderson, S.; Gonzales-Chang, M.; Costanza, R.; Courville, S.; Dalgaard, T.; Dominati, E.; Kubiszewski, I.; Ogilvy, S.; Porfirio, L. A review of methods, data, and models to assess changes in the value of ecosystem services from land degradation and restoration. Ecol. Modell. 2016, 319, 190-207. [CrossRef]

3. Acharya, A.K.; Kafle, N. Land degradation issues in Nepal and its management through agroforestry. J. Agric. Environ. 2009, 10, 133-143. [CrossRef]

4. Pimentel, D. Soil erosion: A food and environmental threat. Environ. Dev. Sustain. 2006, 8, 119-137. [CrossRef]

5. Guerra, A.J.T.; Fullen, M.A.; Jorge, M.d.C.O.; Bezerra, J.F.R.; Shokr, M.S. Slope processes, mass movement and soil erosion: A review. Pedosphere 2017, 27, 27-41. [CrossRef]

6. Karkee, K. Land degradation in Nepal: A Menace to Economy and Ecosystems. Master's Thesis, Lund University, Lund, Sweden, 2004.

7. Ghimire, C.P.; Bonell, M.; Bruijnzeel, L.A.; Coles, N.A.; Lubczynski, M.W. Reforesting severely degraded grassland in the Lesser Himalaya of Nepal: Effects on soil hydraulic conductivity and overland flow production. J. Geophys. Res. Earth Surf. 2013, 118, 2528-2545. [CrossRef] 
8. Gardner, R.; Gerrard, A. Runoff and soil erosion on cultivated rainfed terraces in the Middle Hills of Nepal. Appl. Geogr. 2003, 23, 23-45. [CrossRef]

9. Gautam, D.R. Environmental Risk in Nepal: A General Assessment. Tribhuvan Univ. J. 1993, 16, 87-93.

10. Uddin, K.; Murthy, M.; Wahid, S.M.; Matin, M.A. Estimation of soil erosion dynamics in the Koshi basin using GIS and remote sensing to assess priority areas for conservation. PLoS ONE 2016, 11, e0150494. [CrossRef] [PubMed]

11. Chalise, D.; Kumar, L.; Shriwastav, C.P.; Lamichhane, S. Spatial assessment of soil erosion in a hilly watershed of Western Nepal. Environ. Earth Sci. 2018, 77, 685. [CrossRef]

12. Carson, B. Erosion and Sedimentation Processes in the Nepalese Himalya; ICIMOD Occasional Paper No. 1; ICIMOD: Kathmandu, Nepal, 1985.

13. Byers, A.C. Landscape change and man-accelerated soil loss: The case of the Sagarmatha National Park. Mt. Res. Dev. 1987, 7, 209-216. [CrossRef]

14. Sherchan, D.; Chand, S. A review of current soils related research activities at Pakhribas Regional Agricultural Centre. In Proceedings of the Soil Fertility and Erosion Issues in the Middle Mountains of Nepal, Ottawa, Canada, 22-25 April 1991; pp. 83-104.

15. Maskey, R.; Joshi, D. Soil and nutrient losses under different soil management in the middle mountains of Nepal. In Proceedings of the Soil Fertility and Erosion Issues in the Middle Mountains Nepal, Ottawa, Canada, 22-25 April 1991; pp. 105-120.

16. Ries, J. Soil Erosion in the High Mountain Regions, Eastern Central Himalaya. A Case Study in Bamti/Bhandara/Surma Area. Ph.D. Thesis, Albert-LudwigsUniversitàt, Freiburg, Germany, 1993.

17. Watanabe, T. Soil erosion on Yak-grazing steps in the Langtang Himal, Nepal. Mt. Res. Dev. 1994, 14, 171-179. [CrossRef]

18. Carver, M.; Nakarmi, G. The effect of surface conditions on soil erosion and stream suspended sediments. In Proceedings of the Challenges in Mountain Resource Management in Nepal: Processes, Trends and Dynamics in Middle Mountain Watersheds, Ottawa, Canada, 10-12 April 1995; pp. 155-162.

19. Watershed Management Project. Department of Soil Conservation. Kulekhani Soil Loss and Runoff Plot. Annual Report 1994/95; Watershed Management Project: Kathmandu, Nepal, 1995.

20. Watershed Management Project. Department of Soil Conservation. Soil Loss and Runoff Study at Subbakuna Demonstration Centre, Surkhet. Annual Report 1994/95; Watershed Management Project: Kathmandu, Nepal, 1995.

21. Shrestha, A.B.; Aryal, R. Climate change in Nepal and its impact on Himalayan glaciers. Reg. Environ. Chang. 2011, 11, 65-77. [CrossRef]

22. Joshi, A.R.; Shrestha, S.L.; Joshi, K. Environmental management and sustainable development at the crossroad. Mt. Res. Dev. 2003, 26, 383-384.

23. Ministry of Environment Science and Technology. Third National Report on the Implementation of UN Convention to Combat Desertification; Ministry of Environment Science and Technology: Kathmandu, Nepal, 2006.

24. Carson, B. The land, the Farmer and the Future: A soil fertility Management Strategies for Nepal. Presented at International Centre for Integrated Mountain Development (ICIMOD), Kathmandu, Nepal, 1992.

25. Joshy, D.; Pandey, S.; Munankarmy, R. The Role of Integrated Plant Nutrition Systems in Sustainable and Environmentally Sound Agricultural Development; RAPA Publication (FAO): Kathmandu, Nepal, 1993.

26. Government of Nepal, Ministry of Environment, Science and Technology. Nepal Thematic Assessment Report: Land Degradation; Government of Nepal, Ministry of Environment, Science and Technology: Kathmandu, Nepal, 2008.

27. Zuazo, V.H.D.; Pleguezuelo, C.R.R. Soil-erosion and runoff prevention by plant covers. A review. In Sustainable Agriculture; Lichtfouse, E., Navarrete, M., Debaeke, P., Veronique, S., Alberola, C., Eds.; Springer: Dordrecht, The Netherlands, 2009; pp. 785-811.

28. Acharya, G.P.; McDonald, M.A.; Tripathi, B.P.; Gardner, R.M.; Mawdesley, K.J. Nutrient losses from rain-fed bench terraced cultivation systems in high rainfall areas of the mid-hills of Nepal. Land Degrad. Dev. 2007, 18, 486-499. [CrossRef]

29. Bajracharya, R.M.; Sherchan, D.P. Fertility status and dynamics of soils in the Nepal Himalaya: A review and analysis. In Soil Fertility; Nova Science Publishers, Inc.: New York, NY, USA, 2009; pp. 111-135. 
30. Bayramin, İ.; Basaran, M.; Erpul, G.; Canga, M.R. Assessing the effects of land use changes on soil sensitivity to erosion in a highland ecosystem of semi-arid Turkey. Environ. Monit. Assess. 2008, 140, 249-265. [CrossRef] [PubMed]

31. Ochoa-Cueva, P.; Fries, A.; Montesinos, P.; Rodríguez-Díaz, J.A.; Boll, J. Spatial estimation of soil erosion risk by land-cover change in the Andes of southern Ecuador. Land Degrad. Dev. 2015, 26, 565-573. [CrossRef]

32. Simonneaux, V.; Cheggour, A.; Deschamps, C.; Mouillot, F.; Cerdan, O.; Le Bissonnais, Y. Land use and climate change effects on soil erosion in a semi-arid mountainous watershed (High Atlas, Morocco). J. Arid. Environ. 2015, 122, 64-75. [CrossRef]

33. Zare, M.; Mohammady, M.; Pradhan, B. Modeling the effect of land use and climate change scenarios on future soil loss rate in Kasilian watershed of northern Iran. Environ. Earth Sci. 2017, 76, 305. [CrossRef]

34. Anache, J.A.; Flanagan, D.C.; Srivastava, A.; Wendland, E.C. Land use and climate change impacts on runoff and soil erosion at the hillslope scale in the Brazilian Cerrado. Sci. Total Environ. 2018, 622, 140-151. [CrossRef] [PubMed]

35. Li, L.; Wang, Y.; Liu, C. Effects of land use changes on soil erosion in a fast developing area. Int. J. Environ. Sci. Technol. 2014, 11, 1549-1562. [CrossRef]

36. Chalise, D.; Kumar, L. Land Use Change Impacts on Soil Erosion Dynamics in Western Nepal; University of New England: Armidale, Australia, 2018.

37. Morgan, R.P.C. Soil Erosion and Conservation, 3rd ed.; Blackwell Publishing: Massachusetts, MA, USA, 2009.

38. Harper, D. Improving the accuracy of the universal soil loss equation in Thailand. In Proceedings of the Fifth International Conservation Conferences, Bangkok, Thailand, 1987.

39. Chalise, S.; Khanal, N. Erosion processes and their implications in sustainable management of watersheds in Nepal Himalayas. In Proceedings of the Regional Hydrology: Concepts and Models for Sustainable Water Resource Management, Postojna, Slovenia, 30 September-4 October 1997; pp. 325-334.

40. Thapa, G.; Paudel, G. Farmland degradation in the mountains of Nepal: A study of watersheds 'with'and 'without'external intervention. Land Degrad. Dev. 2002, 13, 479-493. [CrossRef]

41. Holz, D.J.; Williard, K.W.; Edwards, P.J.; Schoonover, J.E. Soil erosion in humid regions: A review. J. Contemp. Water Res. Educ. 2015, 154, 48-59. [CrossRef]

42. Upreti, B. The physiography and geology of Nepal and their bearing on the landslide problem. In Landslide Hazard Mitigation in the Hindu Kush-Himalayas; International Centre for Integrated Mountain Development: Kathmandu, Nepal, 2001; pp. 31-49.

43. Atreya, K.; Sharma, S.; Bajracharya, R.M.; Rajbhandari, N.P. Developing a sustainable agro-system for central Nepal using reduced tillage and straw mulching. J. Environ. Manag. 2008, 88, 547-555. [CrossRef] [PubMed]

44. Atreya, K.; Sharma, S.; Bajracharya, R.M.; Rajbhandari, N.P. Applications of reduced tillage in hills of central Nepal. Soil Tillage Res. 2006, 88, 16-29. [CrossRef]

45. Bajaracharya, R.M. Land preparation: An integral part of farming systems in the mid-hills of Nepal. Nepal J. Sci. Technol. 2015, 3.

46. Mohammad, A.G.; Adam, M.A. The impact of vegetative cover type on runoff and soil erosion under different land uses. Catena 2010, 81, 97-103. [CrossRef]

47. Atreya, K. Management Effects on Soil and Nutrient Losses and Crop Productivity in Maize-Based Cropping Systems of the Central Nepal Mid-Hills. Master's Thesis, Kathmandu University, Kathmandu, Nepal, 2002.

48. Schreier, H.; Shah, P. Soil fertility status and dynamics in the Jhikhu and Yarsha Khola watersheds. In Proceedings of the People and Resource Dynamics Project: The First Three Years (1996-1999), Baoshan, China, 2-5 March 1999; pp. 281-289.

49. Lal, R.; Ahmadi, M.; Bajracharya, R. Erosional impacts on soil properties and corn yield on Alfisols in central Ohio. Land Degrad. Dev. 2000, 11, 575-585. [CrossRef]

50. Cihacek, L.; Swan, J. Effects of erosion on soil chemical properties in the north central region of the United States. J. Soil Water Conserv. 1994, 49, 259-265.

51. Posthumus, H.; Deeks, L.; Rickson, R.; Quinton, J. Costs and benefits of erosion control measures in the UK. Soil Use Manag. 2015, 31, 16-33. [CrossRef]

52. Thapa, B.; Cassel, D.; Garrity, D.P. Assessment of tillage erosion rates on steepland Oxisols in the humid tropics using granite rocks. Soil Tillage Res. 1999, 51, 233-243. [CrossRef]

53. Pimentel, D.; Burgess, M. Soil erosion threatens food production. Agriculture 2013, 3, 443-463. [CrossRef] 
54. Panagos, P.; Borrelli, P.; Meusburger, K.; Alewell, C.; Lugato, E.; Montanarella, L. Estimating the soil erosion cover-management factor at the European scale. Land Use Policy 2015, 48, 38-50. [CrossRef]

55. Evette, A.; Labonne, S.; Rey, F.; Liebault, F.; Jancke, O.; Girel, J. History of bioengineering techniques for erosion control in rivers in Western Europe. Environ. Manag. 2009, 43, 972. [CrossRef] [PubMed]

56. Morgan, R.P.; Rickson, R.J. Slope Stabilization and Erosion Control: A Bioengineering Approach; Taylor \& Francis: London, UK, 2003.

57. Ligonja, P.; Shrestha, R. Soil erosion assessment in kondoa eroded area in Tanzania using universal soil loss equation, geographic information systems and socioeconomic approach. Land Degrad. Dev. 2015, 26, 367-379. [CrossRef]

58. Johnson, N.; Ravnborg, H.M.; Westermann, O.; Probst, K. User participation in watershed management and research. Water Policy 2002, 3, 507-520. [CrossRef]

59. KC, T.B.; Ojha, R.B. An. Introduction to Soils, Soil Fertility and Soil Conservation; Heritage Publishers and Distributors Pvt. Ltd.: Kathmandu, Nepal, 2016.

60. Ramos, M.C.; Quinton, J.N.; Tyrrel, S.F. Effects of cattle manure on erosion rates and runoff water pollution by faecal coliforms. J. Environ. Manag. 2006, 78, 97-101. [CrossRef] [PubMed]

61. Acharya, G.P.; Tripathi, B.P.; Gardner, R.M.; Mawdesley, K.J.; McDonald, M.A. Sustainability of sloping land cultivation systems in the mid-hills of Nepal. Land Degrad. Dev. 2008, 19, 530-541. [CrossRef]

62. Higaki, D.; Karki, K.K.; Gautam, C.S. Soil erosion control measures on degraded sloping lands: A case study in Midlands of Nepal. Aquat. Ecosyst. Health Manag. 2005, 8, 243-249. [CrossRef]

63. Tiwari, K.R.; Sitaula, B.K.; Bajracharya, R.M.; Borresen, T. Runoff and soil loss responses to rainfall, land use, terracing and management practices in the Middle Mountains of Nepal. Acta Agric. Scand. B Soil Plant. Sci. 2008, 59, 197-207. [CrossRef]

64. Dhital, Y.P.; Kayastha, R.B.; Shi, J. Soil bioengineering application and practices in Nepal. Environ. Manag. 2013, 51, 354-364. [CrossRef] [PubMed]

65. Dhital, Y.P.; Tang, Q. Soil bioengineering application for flood hazard minimization in the foothills of Siwaliks, Nepal. Ecol. Eng. 2015, 74, 458-462. [CrossRef]

66. Ya, T.; Nakarmi, G. Effect of contour hedgerows of nitrogen-fixing plants on soil erosion of sloping agricultural land. Impact of Contour Hedgerows: A Case Study. Presented at ICIMOD, Kathmandu, Nepal, 8-11 September 2004.

67. Lamichhane, K. Effectiveness of sloping agricultural land technology on soil fertility status of mid-hills in Nepal. J. For. Res. 2013, 24, 767-775. [CrossRef]

68. Hartwig, N.L.; Ammon, H.U. Cover crops and living mulches. Weed Sci. 2002, 50, 688-699. [CrossRef]

69. Raya, A.M.; Zuazo, V.; Martínez, J. Soil erosion and runoff response to plant-cover strips on semiarid slopes (SE Spain). Land Degrad. Dev. 2006, 17, 1-11. [CrossRef]

70. Quinton, J.N.; Catt, J. The effects of minimal tillage and contour cultivation on surface runoff, soil loss and crop yield in the long-term Woburn Erosion Reference Experiment on sandy soil at Woburn, England. Soil Use Manag. 2004, 20, 343-349. [CrossRef]

71. Su, Z.; Zhang, J.; Wu, W.; Cai, D.; Lv, J.; Jiang, G.; Huang, J.; Gao, J.; Hartmann, R.; Gabriels, D. Effects of conservation tillage practices on winter wheat water-use efficiency and crop yield on the Loess Plateau, China. Agric. Water Manag. 2007, 87, 307-314. [CrossRef]

72. Mupangwa, W.; Twomlow, S.; Walker, S.; Hove, L. Effect of minimum tillage and mulching on maize (Zea mays L.) yield and water content of clayey and sandy soils. Phys. Chem. Earth Parts A/B/C 2007, 32, 1127-1134. [CrossRef]

73. Chaowen, L.; Shihua, T.; Jingjing, H.; Yibing, C. Effects of plant hedgerows on soil erosion and soil fertility on sloping farmland in the purple soil area. Acta Ecol. Sin. 2007, 27, 2191-2198. [CrossRef]

74. Government of Nepal, National Planning Commission. National Planning Commission. The Eighth Plan; Government of Nepal, National Planning Commission: Kathmandu, Nepal, 2016.

75. Government of Nepal, National Planning Commission. National Planning Commission. The Ninth Plan; Government of Nepal, National Planning Commission: Kathmandu, Nepal, 2016.

76. Government of Nepal, National Planning Commission. National Planning Commission. Tenth Plan (2002-2007); Government of Nepal, National Planning Commission: Kathmandu, Nepal, 2002. 
77. Government of Nepal, National Planning Commission. National Planning Commission. An Approach Paper to the Thirteenth Plan (2013-2016); Government of Nepal, National Planning Commission: Kathmandu, Nepal, 2013.

78. Government of Nepal, National Planning Commission. National Planning Commission. The Fourteenth Plan; Government of Nepal, National Planning Commission: Kathmandu, Nepal, 2017.

79. SWCA. Soil and Water Conservation Act. 1982. Available online: http://nepalpolicynet.com/ images/documents/forest/acts/Soil\%20and\%20Watershed\%20Conservation\%20Act,\%202039 (accessed on 18 August 2018).

(C) 2019 by the authors. Licensee MDPI, Basel, Switzerland. This article is an open access article distributed under the terms and conditions of the Creative Commons Attribution (CC BY) license (http://creativecommons.org/licenses/by/4.0/). 